\title{
Factors Affecting Enucleation Rates of Bovine and Porcine Oocytes After Removal of Cumulus Cells by Vortexing
}

\author{
Edwin C. ATABAY'1), Mario A. MARTINEZ DIAZ1), Osamu DOCHI') and \\ Yoshiyuki TAKAHASHI)
}

1) Laboratory of Theriogenology, Department of Veterinary Clinical Sciences, Graduate School
of Veterinary Medicine, Hokkaido University, Sapporo 060-0818 and ${ }^{2)}$ Faculty of Dairy
Science, Rakuno Gakuen University, Ebetsu 069-8501, Japan

Abstract. In vitro matured bovine and porcine oocytes were enucleated by aspiration of the first polar body and adjacent cytoplasm after removing the cumulus cells by vortexing and the factors affecting enucleation rate were investigated. The results indicate that vortexing cumulus-oocyte complexes for long periods in hyperosmotic media moves the first polar body and reduces the enucleation rate. Removal of $20 \%$ cytoplasmic volume increased enucleation rate compared with that of $10 \%$ and showed no deleterious effect on subsequent developmental capacity of reconstructed bovine embryos. Aging of oocytes could also reduce enucleation efficiency by inducing the migration of the chromatin material to the center of the oocyte. Therefore, we recommend to enucleate newly matured bovine and porcine oocytes by removing the first polar body and adjacent $20 \%$ of ooplasm after the removal of cumulus cells by vortexing for a short period using a hypo-osmotic media to achieve a high enucleation rate .

Key words: Cattle, Enucleation, Nuclear transfer, Oocyte, Pig

(J. Reprod. Dev. 47: 365-371, 2001)

$\mathbf{T}$ ransplantation of nuclei into enucleated oocytes is currently a major focus of interest in the production of cloned animals. The technique involves the preparation of karyoplast and cytoplast. Production of a suitable cytoplast in nuclear transfer (NT) procedures is considered a critical step. Enucleated MII oocytes are commonly used as recipient cytoplasts. The efficient removal of the cytoplasmic chromatin material before NT is of crucial importance in the production of reconstructed embryos with normal ploidy. However, enucleation of MII oocytes remains a major obstacle with $50-80 \%$ enucleation efficiency [1-4] in cattle. In the pig, enucleation efficiency varies from 60 to $90 \%$ [5-11]. Solving this limitation

Accepted for publication: September 3, 2001

Correspondence: Y. Takahashi would enable the sufficient preparation of recipient cytoplasts for the reconstruction of NT embryos.

The removal of the nuclear material of MII oocytes is typically performed blindly by aspirating a portion of the cytoplasm underlying the first polar body [1, 2, 4-15]. To achieve a high enucleation rate with this procedure, the chromatin material needs to be located near or adjacent to the first polar body. Removal of the cumulus cells surrounding the oocyte is required prior to enucleation. In general, the cumulus cells are removed by vortexing. This method, however, could possibly affect the relationship between the position of the first polar body and the chromatin material. Speculation exists that the possible movement of the first polar body away from the original site of extrusion [2], frequent displacement 
of the chromatin material [16], and the volume of removed cytoplasm during aspiration/bisection might be major causes of low enucleation rates.

The present study was undertaken to investigate the factors affecting the enucleation efficiency of bovine and porcine oocytes after the removal of cumulus cells by vortexing and aspiration of the first polar body and 10 or $20 \%$ of the cytoplasm. We also determined the developmental capacity of bovine NT embryos constructed with cumulus cells and enucleated oocytes with different cytoplasmic volumes.

\section{Materials and Methods}

\section{Oocyte preparation}

In vitro matured, slaughterhouse-derived bovine oocytes were prepared as described elsewhere [17]. Briefly, cumulus-oocyte complexes (COCs) aspirated from small antral follicles $(2-7 \mathrm{~mm}$ in diameter) were washed 3 times with HEPESbuffered modified Tyrodes's medium (TALPHEPES) [18] supplemented with $3 \mathrm{mg} / \mathrm{ml}$ bovine serum albumin (BSA, Fraction V, Sigma Chemical Co., St. Louis, MO, USA), $0.2 \mathrm{mM}$ sodium pyruvate (Sigma) and $50 \mu \mathrm{g} / \mathrm{ml}$ gentamycin sulfate (Sigma). The COCs were then cultured in HEPES-buffered TCM 199 (Gibco Laboratories, Grand Island, NY, USA) supplemented with $10 \%$ fetal calf serum (FCS, Gibco), 0.02 units/ml FSH (from porcine pituitary, Sigma), $1 \mu \mathrm{g} / \mathrm{ml}$ estradiol- $17 \beta$ (Sigma), $0.2 \mathrm{mM}$ sodium pyruvate and $50 \mu \mathrm{g} / \mathrm{ml}$ gentamycin sulfate. Ten to twelve oocytes were cultured for $18-20 \mathrm{~h}$ in a $50-\mu \mathrm{l}$ droplet of maturation medium overlaid with paraffin oil (Nacalai Tesque Inc., Kyoto, Japan) under a humidified atmosphere of $5 \% \mathrm{CO}_{2}$ in air at $39 \mathrm{C}$.

Porcine oocyte-cumulus-granulosa-complexes (OCGCs) collected from abattoir-derived ovaries were cultured to induce maturation as described previously [10]. Briefly, healthy follicles with 4-6 $\mathrm{mm}$ of diameter were dissected in HEPES-buffered TCM 199 supplemented with 0.1\% PVA (Sigma). OCGCs were collected in the same medium by scraping the inner surface of the follicles with a pair of forceps. Five OCGCs were cultured in a $100-\mu \mathrm{l}$ drop of BSA-free North Carolina State University Medium 23 (NCSU-23) [19] supplemented with $0.57 \mathrm{mM}$ cystein $($ Sigma), $10 \%(\mathrm{v} / \mathrm{v})$ porcine follicular fluid, $10 \mathrm{IU} / \mathrm{ml}$ eCG (Teikoku Hormone
Mfg. Co. Ltd., Tokyo, Japan) and 10 IU/ml hCG (Teikoku Hormone) under a humidified atmosphere of $5 \% \mathrm{CO}_{2}$ in air at $39 \mathrm{C}$ for $20 \mathrm{~h}$. The oocytes were further cultured in the same medium without hormones for another 22-24 h.

The bovine COCs and porcine OCGCs were vortexed (Vortex-Genie 2, Scientific Industries Inc., Bohemia, NY, USA) for 0.5 or $3 \mathrm{~min}$ in a $1.5-\mathrm{ml}$ testtube (Dorika Co. Ltd., Sapporo, Japan ) containing $200 \mu \mathrm{l}$ of TALP-HEPES with $0.1 \%$ hyaluronidase (Type 1-S, Sigma). The cumulus cells of some bovine and porcine oocytes were removed by repeated pipetting.

\section{Oocyte enucleation}

After the removal of cumulus cells, denuded bovine and porcine oocytes were mechanically enucleated by removing the first polar body and approximately $10(7.1 \pm 3.2, \mathrm{n}=42)$ or $20 \%(19.8 \pm 1.4$, $\mathrm{n}=38$ ) of the adjacent cytoplasm with a $30-\mu \mathrm{m}$ (outer diameter) glass pipette. To regulate the volume of aspirated cytoplasm, the reference point of removed ooplasm inside the injection pipette during enucleation was determined in a preliminary study by measuring the oocyte diameter before and after enucleation and calculation of cytoplasmic volume as described previously [20]. Enucleation was carried out using an inverted microscope (Diaphot, Nikon, Tokyo, Japan) with Narashige (Narashige Co. Ltd., Tokyo, Japan) micromanipulators in a $40-\mu$ ldrop of TALPHEPES supplemented with $10 \%$ FCS and $5 \mu \mathrm{g} / \mathrm{ml}$ cytochalasin B (Sigma). Enucleated oocytes were incubated in $\mathrm{Ca}^{2+}$ - and $\mathrm{Mg}^{2+}$-free Dulbecco's phosphate-buffered saline (DPBS) containing 3 $\mathrm{mg} / \mathrm{ml} \mathrm{BSA}$ and $5 \mu \mathrm{g} / \mathrm{ml}$ Hoechst 33342 (Sigma) for $15 \mathrm{~min}$ at $39 \mathrm{C}$. Oocytes were examined individually under an inverted microscope (Eclipse TE 300, Nikon) equipped with an epifluorescence (TE-FM, Nikon) and UV-1A filter block (365 nm excitation and $400 \mathrm{~nm}$ emission) to confirm enucleation.

\section{Nuclear transfer, fusion, activation and culture}

Primary cultured bovine cumulus cells were prepared as described previously [21]. Briefly, collected cumulus cells from in vitro matured bovine oocytes in TALP-HEPES with $0.1 \%$ hyaluronidase were washed three times with DMEM/F12 (Gibco) by centrifugation. The concentration and viability of the separated cells 
were determined and then cultured in DMEM/F12 $+10 \%$ FCS at a concentration of $8-9 \times 10^{4}$ cells $/ \mathrm{ml}$ in $60 \times 10 \mathrm{~mm}$ dishes (Falcon 3802, Becton Dickinson Labware, Franklin Lakes, NJ, USA) under a humidified atmosphere of $5 \% \mathrm{CO}_{2}$ in air at $37 \mathrm{C}$. Cultured cells were allowed to multiply for 3-4 days, and thereafter were deprived of serum source $(0.5 \%$ FCS $)$ for 3 days. After serum-starved culture, the cells were disaggregated with $\mathrm{Ca}^{2+}$ - and $\mathrm{Mg}^{2+}$-free DPBS containing $0.1 \%(\mathrm{w} / \mathrm{v})$ trypsin (Sigma) and $0.1 \%(\mathrm{w} / \mathrm{v})$ EDTA (Kanto Chemical Co. Inc., Tokyo, Japan) and used as karyoplasts. In a separate experiment, DNA content analysis using flow cytometry of serum-starved primary cumulus cells revealed that around $95 \%(n=3)$ of mediumsized cells were at the G0/G1-stage, and that the percentage of live cells was $95 \%(n=3)$.

Trypsinized cumulus cells were inserted individually into the perivitelline space of the enucleated oocytes. The couplets were placed and manually aligned between two wire electrodes (1.0 $\mathrm{mm}$ apart) overlaid with $0.3 \mathrm{M}$ mannitol (Kanto) solution containing $0.1 \mathrm{mM} \mathrm{CaCl}_{2}$ (Kanto) and 0.1 $\mathrm{mM} \mathrm{MgCl} 2$ (Kanto). Cell fusion and activation were simultaneously induced by two direct current pulses of $100 \mathrm{~V} / \mathrm{mm}$ for $40 \mu \mathrm{sec}, 1 \mathrm{sec}$ apart using an Electro Cell Fusion (LF-100, Life Tec Co., Tokyo, Japan). After $1 \mathrm{~h}$, successfully fused couplets were transferred to a modified synthetic oviductal fluid [17] supplemented with 20 amino acids (Sigma), 10 $\mu \mathrm{g} / \mathrm{ml}$ insulin (Sigma), $5 \mathrm{mM}$ glycine (Sigma), 5 $\mathrm{mM}$ taurine (Sigma), $1 \mathrm{mM}$ glucose (Kanto), $1 \mathrm{mM}$ L-glutamine (Sigma), $3 \mathrm{mg} / \mathrm{ml}$ fatty acid-free BSA (Sigma) and $10 \mu \mathrm{g} / \mathrm{ml}$ cycloheximide (CHX, Sigma) for a period of $5 \mathrm{~h}$ at $39 \mathrm{C}$ in $5 \% \mathrm{CO}_{2}, 5 \% \mathrm{O}_{2}$ and $90 \%$ $\mathrm{N}_{2}$. After $\mathrm{CHX}$ treatment, the reconstituted embryos were thoroughly washed and then placed in the culture medium excluding $\mathrm{CHX}$ at $39 \mathrm{C}$ in 5\% $\mathrm{CO}_{2}, 5 \% \mathrm{O}_{2}$ and $90 \% \mathrm{~N}_{2}$. The fusion and cleavage rates were determined at 1 and $33 \mathrm{~h}$ post fusion (hpf), respectively. Development to blastocyst and the cell numbers [22] were determined $174 \mathrm{hpf}$.

\section{Experimental design}

In experiment 1 , the cytoplasmic chromatin distribution of MII bovine and porcine oocytes were determined. In vitro matured bovine COCs were divided randomly into three treatment groups wherein the cumulus cells were removed by: 1) repeated pipetting in TALP-HEPES with $0.1 \%$ hyaluronidase, 2 ) pipetting and vortexing for
$0.5 \mathrm{~min}$, and 3) vortexing for $3 \mathrm{~min}$. In vitro matured porcine oocytes were denuded following the procedure of 1) or 3) described above. Oocytes with the first polar body were incubated in Hoechst 33342 stain. The location of chromatin material was determined using the first polar body as a reference point (Fig. 1). In experiment 2 , the enucleation efficiency with the removal of 10 or $20 \%$ of the cytoplasmic volume was determined. The oocytes were denuded and grouped as in experiment 1 and enucleated blindly. In experiment 3 , the developmental capacity of reconstituted bovine embryos constructed with enucleated oocytes with approximately 80 or $90 \%$ of its original cytoplasmic volume and serum-starved primary cumulus cells was investigated to determine the effect of reduced ooplasmic volume in somatic NT. In experiment 4 , we examined whether the first polar body of bovine and porcine oocytes could be moved by vortexing. After initial staining with Hoechst 33342, all oocytes with chromatin location at Position 1 (see Fig. 1) were further vortexed for $5 \mathrm{~min}$ and restained with Hoechst 33342. The cytoplasmic chromatin location was examined thereafter.

\section{Statistical analysis}

Data in experiments 1 and 2 were subjected to one-way analysis of variance (ANOVA) followed by Fisher's protected least significant difference test using StatView software (Abacus Concepts Inc., Berkeley, CA, USA). Differences between two means in experiments 2 and 3 were analyzed using student's $t$-test.

\section{Results}

\section{Experiment 1}

After 3 min of vortexing, bovine oocytes, but not porcine oocytes, showed the lowest proportions that exhibited cytoplasmic chromatin material located at Positions 1 and $2(\mathrm{P}<0.05)$ as shown in Table 1.

\section{Experiment 2}

Three minutes vortexing in bovine oocytes gave a significantly lower enucleation rate than the other treatments $(\mathrm{P}<0.01)$ both in 10 and $20 \%$ removal of cytoplasmic volume. However, removal of $20 \%$ cytoplasmic volume revealed a significantly higher enucleation rate compared with that of $10 \%$ 


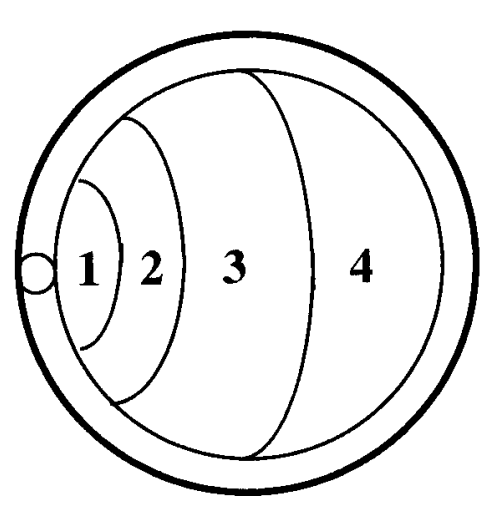

Fig. 1. Schematic presentation of metaphase chromatin relative to the first polar body in in vitro matured bovine and porcine oocytes. 1) Position 1: the metaphase chromatin is located immediately adjacent to the polar body. 2) Position 2: at the cytoplasmic third near the polar body but not in close association. 3) Position 3: at the midcytoplasmic third. 4) Position 4: at the cytoplasmic third far from the polar body.

$(\mathrm{P}<0.05)$ both in bovine and porcine oocytes as shown in Table 2.

\section{Experiment 3}

As shown in Table 3, no significant differences were observed in fusion, cleavage, development to the blastocyst stage and cell number of blastocysts between the two experimental groups.

\section{Experiment 4}

As shown in Table 4, 40\% (14/35) of porcine oocytes and $60 \%(12 / 20)$ of bovine oocytes showed displacement of the chromatin material from
Position 1 after vortexing for $5 \mathrm{~min}$. The chromatin materials were located peripherally in all of the oocytes that were observed at Positions 2-4.

\section{Discussion}

The results of this study clearly indicate that prolonged vortexing changes the location of the first polar body relative to the chromatin material, and supports the previous finding that the metaphase spindle of $60 \%$ of bovine oocytes was displaced from the previously assumed location subjacent to the first polar body during cytoplast preparation [16]. Under the same condition of vortexing $(3 \mathrm{~min})$, porcine oocytes kept the first polar body near the site of extrusion probably due to the smaller perivitelline space and the higher cytoplasmic osmolarity compared with bovine oocytes. The higher proportion of bovine oocytes which showed first polar body movement from the site of extrusion during cumulus removal might be due to the large perivitelline space. The use of a hyperosmotic media induces shrinkage of the ooplasma and polar body leading to an enlargement of the perivitelline space. Thus, a hypo-osmotic media should be used during the vortexing process.

This study demonstrates that minimizing the time of vortexing to remove the cumulus cells of MII oocytes supports a high enucleation rate by maintaining the first polar body close to the site of extrusion. After 10\% removal of cytoplasmic volume during enucleation, only MII oocytes with chromatin material at Position 1 could be

Table 1. Cytoplasmic chromatin distribution after cumulus cell removal by repeated pipetting or vortexing of in vitro matured bovine and porcine oocytes

\begin{tabular}{|c|c|c|c|c|c|c|}
\hline \multirow[t]{2}{*}{ Treatment for cumulus removal } & \multirow{2}{*}{$\begin{array}{c}\text { No.of } \\
\text { oocytes } \\
\text { (replicates) }\end{array}$} & \multicolumn{5}{|c|}{$\%$ of oocytes with chromatin at position ${ }^{a}$} \\
\hline & & 1 & 2 & 3 & 4 & $1+2$ \\
\hline \multicolumn{7}{|l|}{ Bovine } \\
\hline Pipetting & $43(3)$ & $76.8 \pm 3.3^{\mathrm{b}}$ & $11.5 \pm 3.3^{\mathrm{b}}$ & $4.8 \pm 4.2^{\mathrm{b}}$ & $7.0 \pm 0.6^{b}$ & $88.3 \pm 4.2^{\mathrm{b}}$ \\
\hline Pipetting+ $0.5 \mathrm{~min}$ vortexing & $65(3)$ & $76.5 \pm 11.4^{\mathrm{b}}$ & $11.7 \pm 1.4^{\mathrm{b}}$ & $5.8 \pm 4.6^{\mathrm{b}}$ & $5.9 \pm 6.8^{b}$ & $88.2 \pm 9.5^{\mathrm{b}}$ \\
\hline 3 min vortexing & $63(3)$ & $32.0 \pm 5.5^{c}$ & $32.0 \pm 5.1^{c}$ & $17.2 \pm 3.8^{\mathrm{c}}$ & $18.7 \pm 3.7^{c}$ & $64.0 \pm 4.8^{c}$ \\
\hline \multicolumn{7}{|l|}{ Porcine } \\
\hline Pipeting & $75(3)$ & $77.6 \pm 3.7^{b}$ & $18.7 \pm 1.2^{\mathrm{b}}$ & $3.7 \pm 3.6^{\mathrm{b}}$ & $0^{\mathrm{b}}$ & $96.3 \pm 3.6^{b}$ \\
\hline 3 min vortexing & $79(3)$ & $76.5 \pm 7.4^{\mathrm{b}}$ & $22.2 \pm 6.8^{b}$ & $1.3 \pm 2.2^{\mathrm{b}}$ & $0^{\mathrm{b}}$ & $98.7 \pm 2.2^{\mathrm{b}}$ \\
\hline
\end{tabular}

a See Fig. 1.

$\mathrm{b}, \mathrm{c}$ Values (means $\pm S D$ ) with different superscripts within a column differ significantly $(\mathrm{P}<0.05)$. 
Table 2. Enucleation rate after the removal of 10 or $20 \%$ cytoplasmic volume of in vitro matured bovine and porcine oocytes after removal of cumulus cells by repeated pipetting or vortexing

\begin{tabular}{|c|c|c|c|c|}
\hline \multirow[b]{2}{*}{ Treatment for cumulus removal } & \multicolumn{2}{|c|}{$10 \%$ removal } & \multicolumn{2}{|c|}{$20 \%$ removal } \\
\hline & $\begin{array}{c}\text { No. of } \\
\text { oocytes } \\
\text { (replicates) }\end{array}$ & $\begin{array}{c}\% \text { of } \\
\text { enucleated }\end{array}$ & $\begin{array}{c}\text { No. of } \\
\text { oocytes } \\
\text { (replicates) }\end{array}$ & $\begin{array}{c}\% \text { of } \\
\text { enucleated }\end{array}$ \\
\hline \multicolumn{5}{|l|}{ Bovine } \\
\hline Pipetting & $49(3)$ & $67.2 \pm 4.1^{\mathrm{a}}$ & $43(3)$ & $88.2 \pm 4.6^{\mathrm{a} *}$ \\
\hline Pipetting +0.5 min vortexing & $81(3)$ & $65.2 \pm 0.8^{\mathrm{a}}$ & $77(4)$ & $89.2 \pm 2.7^{\mathrm{a} *}$ \\
\hline 3 min vortexing & $89(3)$ & $26.4 \pm 0.5^{\mathrm{b}}$ & $76(4)$ & $60.4 \pm 1.2^{\mathrm{b} *}$ \\
\hline \multicolumn{5}{|l|}{ Porcine } \\
\hline Pipetting & $69(3)$ & $63.9 \pm 0.8^{\mathrm{a}}$ & $75(3)$ & $84.2 \pm 2.1^{\mathrm{a} *}$ \\
\hline 3 min vortexing & $86(3)$ & $63.3 \pm 5.1^{\mathrm{a}}$ & $92(4)$ & $82.5 \pm 8.3^{\mathrm{a} *}$ \\
\hline
\end{tabular}

a,b Values (means $\pm \mathrm{SD}$ ) with different superscripts within a column differ significantly $(\mathrm{P}<0.01)$.

*Values (means $\pm \mathrm{SD}$ ) with asterisks differ significantly from those of $10 \%$ removal $(\mathrm{P}<0.05)$.

Table 3. Developmental competence of bovine nuclear transfer embryos constructed with cumulus cells and enucleated oocytes derived from two different cytoplasmic volumes

\begin{tabular}{|c|c|c|c|c|c|c|}
\hline \multirow{2}{*}{$\begin{array}{l}\% \text { of removed } \\
\text { cytoplasmic } \\
\text { volume }\end{array}$} & \multirow{2}{*}{$\begin{array}{c}\text { No. of } \\
\text { couplets } \\
\text { (replicates) }\end{array}$} & \multirow{2}{*}{$\begin{array}{c}\% \text { of } \\
\text { fused } \\
\text { couplets }\end{array}$} & \multicolumn{3}{|c|}{$\%$ of embryos developed to ${ }^{a}$} & \multirow{2}{*}{$\begin{array}{l}\text { Blastocyst } \\
\text { cell no. } \\
\text { (n) }\end{array}$} \\
\hline & & & $\geq 2$-cell & $\geq 8$-cell & blastocysts & \\
\hline 10 & $86(3)$ & $68.8 \pm 1.1$ & $74.0 \pm 2.8$ & $59.6 \pm 8.6$ & $37.3 \pm 8.8$ & $177.7 \pm 7.7(22)$ \\
\hline 20 & $109(6)$ & $68.5 \pm 1.8$ & $76.5 \pm 3.4$ & $57.0 \pm 1.6$ & $35.4 \pm 4.5$ & $176.3 \pm 9.5(25)$ \\
\hline
\end{tabular}

a Values (means $\pm \mathrm{SD}$ ) are based on the numbers of fused couplets.

Development of NT embryos at $\geq 2$-cell, $\geq 8$-cell and blastocyst stages were determined at 33, 72 and $174 \mathrm{~h}$ after fusion, respectively.

Table 4. Cytoplasmic chromatin distribution of bovine and porcine oocytes with initial chromatin location at Position 1 after vortexing for $5 \mathrm{~min}$

\begin{tabular}{lccccc}
\hline \multirow{2}{*}{$\begin{array}{c}\text { Animal } \\
\text { species }\end{array}$} & $\begin{array}{c}\text { No. of } \\
\text { oocytes used }\end{array}$ & \multicolumn{4}{c}{ \% of oocytes with chromatin at position } \\
\cline { 2 - 5 } & 20 & 40.0 & 2 & 3 & \multicolumn{1}{c}{4} \\
\hline Bovine & 20.0 & 15.0 & 5.0 \\
Porcine & 35 & 60.0 & 28.6 & 11.4 & 0 \\
\hline
\end{tabular}

a See Fig. 1.

Data were pooled from 3 replicates.

succesfully enucleated both in cattle and pigs. Mohamed and Takahashi [4] indicated that only bovine MII oocytes with chromatin material at Positions 1 and 2 can be successfully enucleated after removing the first polar body and approximately $20 \%$ of adjacent cytoplasm. The present results support their findings. The results in the porcine oocytes showed that only a few oocytes at Position 2 were successfully enucleated. This is probably due to the use of the same size of pipette during enucleation; the pipette could not be inserted deeply into the ooplasm due to the smaller size of porcine oocytes compared with bovine oocytes.

Enucleation of a bovine oocyte with a volume of cytoplasm similar to that of the nuclear donor cell was found to be more favorable for the development of bovine NT embryos than enucleation with minimum or large volumes of cytoplasm [20]. With embryonic blastomeres as donors, a $50 \%$ reduction of the recipient oocyte volume decreased blastocyst development after 
nuclear transfer [20, 23] and lowered blastocyst cell number $[24,25]$ in cattle. However, replacing the removed cytoplasm during enucleation with an equal amount or increasing it to twice the original volume with cytoplasm obtained from another enucleated oocyte increased blastocyst development [23] and cell numbers [24] in cattle. Similar development rates of bovine NT embryos to the blastocyst stage and blastocyst cell numbers in both tested groups (10 and $20 \%$ reduced cytoplasm) indicate the absence of a deleterious effect on the subsequent developmental capacity of somatic NT embryos reconstructed with enucleated oocytes containing $80 \%$ of the original cytoplasmic volume.

Duration of in vitro maturation culture influences the enucleation efficiency of cattle [26], sheep [15] and pig [7] oocytes. Enucleation rates decrease in aged oocytes matured in vitro. Postovulatory aging in mouse oocytes induces the migration of the second meiotic spindle towards the center of the oocytes due to the disappearance of the microfilament-rich domain [27]. This microfilament-rich domain is responsible for the maintenance of the meiotic spindle and chromosomes in the peripheral position of rat [27], mouse [28], and pig [29] MII oocytes. In the present study, some bovine and porcine oocytes could have reached the MII stage earlier than the time allowed for the oocytes to mature; $18-20 \mathrm{~h}$ in cattle [30] and $32-36 \mathrm{~h}$ in pig [7], respectively. This might be the reason why not all of the oocytes had the metaphase plate adjacent to the first polar body even after pipetting.

In summary, the present study indicated that prolonged vortexing of COCs using hyperosmotic media moved the first polar body from the original site of extrusion and reduced the enucleation rate both in bovine and porcine oocytes. A lesser volume $(10 \%)$ of ooplasm removal decreased the enucleation rate without any advantages on the subsequent developmental capacity compared with $20 \%$ removal in bovine oocytes. Aging of oocytes may also reduce the enucleation rate by inducing the migration of chromatin material. Therefore, we recommend to enucleate newly matured bovine and porcine oocytes by removing the first polar body and adjacent $20 \%$ of ooplasm after the removal of cumulus cells by vortexing for a short period using a hypo-osmotic media.

\section{Acknowledgements}

This study was supported by Grant-in-Aid for Scientific Reasearch (No. 10556058) from the Japan Society for the Promotion of Science, and for Cooperative Research from Rakuno Gakuen University - Rakuno Gakuen University Dairy Institute (2000-1). The authors gratefully acknowledge the staff members of the Ebetsu Meat Inspection Office for the supply of ovaries.

\section{References}

1. Liu JL, Wang MK, Sun QY, Xu Z, Chen DY. Effect of telophase enucleation on bovine somatic nuclear transfer. Theriogenology 2000; 54: 989-998.

2. Robl JM, Stice SL. Prospects for the commercial cloning of animals by nuclear transplantation. Theriogenology 1989; 31: 75-84.

3. Kono T, Sotomaru Y, Aono F, Takahashi T, Ogiwara I, Sekizawa F, Arai T, Nakahara T. Effect of ooplast activation on the development of oocytes following nucleus transfer in cattle. Theriogenology 1994; 41: 1463-1471.

4. Mohamed Nour MS, Takahashi Y. Preparation of young preactivated oocytes with high enucleation efficiency for bovine nuclear transfer. Theriogenology 1999; 51: 661-666.

5. Terlouw SL, Prather RS, Day BN. In vitro development of nuclear transplant pig embryos. Theriogenology 1992; 37: 309 (abstract).
6. Ott $W$, Schernthaner $W$, Hinterhuber $M$, Holy $T$, Alberio R, Prelle K, Zakhartchenko V. Production of pig embryos by nuclear transfer using porcine fetal fibroblasts as karyoplasts. Theriogenology 2000; 53: 238 (abstract).

7. Ikeda K, Takahashi Y. Effects of maturational age of porcine oocytes on the induction of activation and development in vitro following somatic cell nuclear transfer. J Vet Med Sci 2001; 63: 1003-1008.

8. Prather RS, Sims MM, First NL. Nuclear transplantation in early pig embryos. Biol Reprod 1989; 41: 414-418.

9. Nagashima H, Saito S, Yamakawa H. Development of porcine nuclear transplant embryos from 8-16 cell stage donor nuclei. Theriogenology 1992; 37: 263 (abstract).

10. Cheong HT, Ikeda K, Martinez Diaz MA, Katagiri S, Takahashi Y. Development of reconstituted pig 
embryos by nuclear transfer of cultured cumulus cells. Reprod Fertil Dev 2000; 12: 15-20.

11. Prochazka R, Smith S, Hyttel P, Greve T. Behaviour of pig blastomere nuclei introduced into in vitro matured ooplasm by electrically induced fusion. Theriogenology 1990; 33: 301 (abstract).

12. Prather RS, Barnes FL, Sims MM, Robl JM, Eyestone WH, First NL. Nuclear transplantation in the bovine embryo: assessment of donor nuclei and recipient oocyte. Biol Reprod 1987; 37: 859-866.

13. Stice SL, Keefer CL. Multiple generational bovine embryo cloning. Biol Reprod 1993; 48: 715-719.

14. Westhusin ME, Pryor JH, Bondioli KR. Nuclear transfer in the bovine embryo: A comparison of 5day, 6-day, frozen-thawed, and nuclear transfer donor embryos. Mol Reprod Dev 1991; 28: 119-123.

15. Yang X, Jiang S, Kovacs A, Foote RH. Nuclear totipotency of cultured rabbit morulae to support full-term development following nuclear transfer. Biol Reprod 1992; 47: 636-643.

16. Dominko T, Chan A, Simerly C, Luetjens CM, Hewitson L, Martinovich C, Schatten G. Dynamic imaging of the metaphase II spindle and maternal chromosomes in bovine oocytes: implications for enucleation efficiency verification, avoidance of parthenogenesis, and successful embryogenesis. Biol Reprod 2000; 62: 150-154.

17. Takahashi $\mathbf{Y}$, Hishinuma $\mathbf{M}$, Matsui $\mathbf{M}$, Tanaka $\mathbf{H}$, Kanagawa H. Development of in vitro matured/ fertilized bovine embryos in a chemically defined medium: influence of oxygen concentration in the gas atmosphere. J Vet Med Sci 1996; 58: 897-902.

18. Bavister BD, Leibfried ML, Lieberman G. Development of preimplantation embryos of the golden hamster in a defined culture medium. Biol Reprod 1983; 28: 235-247.

19. Petters RM, Wells KD. Culture of pig embryos. J Reprod Fertil suppl 1993; 48: 61-73.

20. Zakhartchenko V, Stojkovic M, Brem G, Wolf E. Karyoplast-cytoplast volume ratio in bovine nuclear transfer embryos: effect on developmental potential. Mol Reprod Dev 1997; 48: 332-338.

21. Mohamed Nour MS, Ikeda K, Takahashi Y. Bovine nuclear transfer using cumulus cells derived from serum-starved and confluent cultures. J Reprod Dev 2000; 46: 85-92.

22. Takahashi Y, First NL. In vitro development of bovine one-cell embryos: influence of glucose, lactate, pyruvate, amino acids and vitamins. Theriogenology 1992; 37: 963-978.

23. Greising $T$, Monaghan $\mathbf{P}$, Healy A, Gordon A, Gallagher M, Wahid H, Gordon I. The influence of cytoplasmic composition and quantity of cytoplasm in recipient oocytes on the developmental capacity of bovine nuclear transfer embryos. Theriogenology 1994; 41: 208 (abstract).

24. Peura TT, Lewis IM, Trounson AO. The effect of recipient oocyte volume on nuclear transfer in cattle. Mol Reprod Dev 1998; 50: 185-191.

25. Westhusin ME, Collas P, Marek D, Sullivan E, Stepp P, Pryor J, Barnes F. Reducing the amount of cytoplasm available for early embryonic development decreases the quality but not quantity of embryos produced by in vitro fertilization and nuclear transplantation. Theriogenology 1996; 46: 243-252.

26. Barnes F, Endebrock M, Looney C, Powell R, Westhusin M, Bondioli K. Embryo cloning in cattle: the use of in vitro matured oocytes. J Reprod Fertil 1993; 97: 317-320.

27. Zernicka-Goetz M, Kubiak JZ, Antony C, Maro B. Cytoskeletal organization of rat oocytes during metaphase II arrest and following abortive activation: A study by confocal laser scanning microscopy. Mol Reprod Dev 1993; 35: 165-175.

28. Webb M, Howlett SK, Maro B. Parthenogenesis and cytoskeletal organization in aging mouse eggs. J Embryol Exp Morphol 1986; 95: 131-145.

29. Kim NH, Moon SJ, Prather RS, Day BN. Cytoskeletal alteration in aged porcine oocytes and parthenogenesis. Mol Reprod Dev 1996; 43: 513-518.

30. Sirard MA, Florman HM, Leibfried RM, Barnes FL, Sims ML, First NL. Timing of nuclear progression and protein synthesis necessary for meiotic maturation of bovine oocytes. Biol Reprod 1989; 40: 1257-1263. 